\title{
Bioedusiana
}

http://jurnal.unsil.ac.id/index.php/bioed

DOI: https://doi.org/10.37058/bioed.v6i1.2968

Bioedusiana

\section{Analisis Kualitas Pertanyaan Mahasiswa Calon Guru Rumpun Ilmu Pengetahuan Alam Ditinjau dari Pengalaman Belajar}

\section{Quality Analysis of Student Questions for Prospective Teachers of Natural Sciences Teachers Reviewed from Learning Experience}

\author{
Wisnu Juli Wiono ${ }^{1 *}$, Pramudiyanti $^{2}$, Nadya Meriza ${ }^{3}$. \\ 1,2,3 Universitas Lampung, J1. Sumantri Brojonegoro No.1, Bandar Lampung, 35141
}

\begin{abstract}
Abstrak
Kualitas pertanyaan dapat menggambarkan perkembangan tingkat berpikir seseorang. Kegiatan menanya juga merupakan indikasi bahwa seorang peserta didik terlibat secara aktif dalam proses pembelajaran. Tujuan penelitian ini adalah untuk menggambarkan profil kualitas pertanyaan mahasiswa rumpun ilmu pengetahuan alam ditinjau dari pengalaman belajar. Penelitian ini menggunakan metode deskriptif karena bertujuan untuk menggambarkan profil subyek penelitian. Instrumen penelitian berupa angket pengalaman belajar dan matriks pertanyaan. Angket pengalaman belajar digunakan untuk mengungkap gambaran pengalaman belajar mahasiswa selama perkuliahan. Sedangkan, matriks pertanyaan digunakan untuk mengukur tingkat berpikir pada setiap pertanyaan yang dibuat oleh mahasiswa. Populasi penelitian ini adalah seluruh mahasiswa di Jurusan Pendidikan Matematika dan Ilmu Pengetahuan Alam yang telah mengikuti perkuliahan Biologi Dasar. Analisis data menggunakan regresi sederhana menunjukkan bahwa pengalaman belajar mahasiswa tidak berpengaruh secara signifikan terhadap kualitas pertanyaan mahasiswa. Masing-masing program studi memiliki skor t hitung sebesar 0,120 (Pendidikan kimia); 1,341 (Pendidikan fisika); dan 0,578 (Pendidikan biologi). Seluruh skor t hitung bernilai lebih kecil daripada $t$ tabel. Kondisi ini diduga kuat karena fase kegiatan inti pada proses perkuliahan tidak berjalan dengan baik. Berdasarkan analisis data ditemukan bahwa fase kegiatan inti memiliki skor terendah 67,33 yang bermakna cukup.
\end{abstract}

Kata kunci: Kualitas Pertanyaan; Pengalaman Belajar; Ilmu Pengetahuan Alam.

\begin{abstract}
The quality of the question can describe the development of a person's thinking level. The questioning activity is also an indication that a student is actively involved in the learning process. The purpose of this study was to describe the quality profile of the students' questions from a natural science family in terms of their learning experience. This study uses a descriptive method because it aims to describe the profile of research subjects. The research instrument was a learning experience questionnaire and a question matrix. Learning experience questionnaires are used to reveal a picture of student learning experiences during lectures. Meanwhile, the question matrix is used to measure the level of thinking on each question made by students. The population of this study were all students in the Mathematics and Natural Sciences Education Department who had attended Basic Biology courses. Data analysis using simple regression shows that student learning experience does not significantly influence the quality of student questions. Each study program has a t score of 0.120 (chemistry education); 1,341 (Physics education); and 0.578 (Biology education). The entire $t$ score is less than the t table. This condition is strongly suspected because the core activity phase of the lecture process did not go well. Based on the data analysis, it was found that the core activity phase had the lowest score of 67.33 which was significant.
\end{abstract}

Keywords: Quality Questions; Learning Experience; Natural Science.

Article History

Received: November 25 ${ }^{\text {th }}$ 2020; Accepted: April 5 $5^{\text {th }}$ 2021; Published: June 30 $0^{\text {th }}, 2021$

Corresponding Author*

Wisnu Juli Wiono, Affiliation, E-mail: wisnujuliwiono@gmail.com

(C) 2021 Bioedusiana. This is an open access article under the CC BY-SA 4.0 license. (https://creativecommons.org/licenses/by-sa/4.0/) 


\section{PENDAHULUAN}

Pendidikan sains pada Abad 21 menuntut adanya paradigma baru dalam proses pembelajaran. Paradigma yang mengubah teaching (mengajar) ke learning (belajar) atau pembelajaran teacher centered ke pembelajaran student centered. Selaras dengan pernyataan tersebut, Pemerintah Indonesia menanggapi dengan menerapkan kurikulum baru. Penerapan kurikulum 2013 memiliki tujuan untuk meningkatkan peran peserta didik dalam proses pembelajaran. Orientasi proses pembelajaran harus mengakomodasi tahap-tahap pada pendekatan ilmiah (scientific approach). Proses pembelajaran yang terintegrasi pada pendekatan ilmiah meliputi aktivitas (1) mengamati, (2) menanya, (3) mengumpulkan informasi, (4) mengasosiasi dan (5) mengomunikasi. Salah satu kegiatan yang dianggap dapat membangkitkan motivasi peserta didik untuk memulai pembelajaran adalah menanya (Oktaviana et al., 2016). Hal tersebut dapat dilihat dari kebanyakan pendidik yang menggunakan kegiatan menanya sebagai bentuk apersepsi pembelajaran.

Kemampuan menanya yang ditunjukkan oleh peserta didik dapat dijadikan sebagai indikator bagi pendidik untuk mengetahui tingkat penguasaan materi yang telah dipelajari. Selain itu, bentuk pertanyaan yang ditampilkan juga dapat dijadikan sebagai penanda tingkat berpikir yang dominan berkembang pada peserta didik. Fakta di atas menunjukkan bahwa menanya dapat menunjukkan tingkat penguasaan dan tingkat berpikir peserta didik (Widyatama et al., 2016).

Sementara itu, kondisi nyata pelaksanaan pembelajaran yang berorientasi pada pendekatan scientific approach di Kota Bandar Lampung pernah disurvei oleh Hasnunidah (2016). Survai yang dilakukan pada 25 sekolah tersebut menunjukkan bahwa pelaksanaan student centered learning masih mengalami banyak kendala, sehingga sebagian guru (46\%) tidak menggunakan scientific approach secara sistematis, $42 \%$ guru tidak menggunakan sesuai urutan logis, dan hanya $12 \%$ guru yang menggunakannya secara lengkap dan logis (Hasnunidah, 2016).

Beberapa kondisi yang disinyalir menjadi penyebab mahasiswa tidak menanya diantaranya: 1) tidak peduli dengan materi yang dipelajari, 2) tidak ingin terlihat bodoh, dan 3) menanya adalah tugas pendidik (Walsh \& Sattes, 2016). Salah satu cara untuk mereduksi penyebab kurangnya aktivitas menanya pada mahasiswa adalah dengan menerapkan strategi pembelajaran yang tepat. Hal ini sebagaimana pendapat (Nasution, 2016), bahwa strategi pembelajaran adalah pola kegiatan pembelajaran yang dipilih oleh pendidik dengan mempertimbangkan karakteristik peserta didik, lingkungan sekitar dan tujuan pembelajaran yang telah dirumuskan. Banyak strategi pembelajaran yang telah dihasilkan oleh para ilmuwan di dalam dunia pembelajaran. Masing-masing strategi menyesuaikan dengan rumusan tujuan pembelajaran. Berdasarkan latar belakang peneliti ingin mengetahui "Bagaimanakah kualitas pertanyaan mahasiswa calon guru rumpun IPA yang ditinjau dari pengalaman belajar?". 
sehingga tujuan dari penelitian ini adalah untuk menggambarkan profil subyek penelitian dalam membuat pertanyaan yang berkualitas.

\section{METODE}

Penelitian ini menerapkan pendekatan deskriptif asosiatif yang merujuk kepada perlakuan variabel bebas (X) berupa pengalaman belajar yang telah terjadi sebelumnya dan melihat efeknya pada variabel terikat $(\mathrm{Y})$ yaitu kualitas pertanyaan mahasiswa. Populasi penelitian ini adalah mahasiswa JPMIPA FKIP Universitas Lampung TA 2019/2020. Sampel dipilih secara purposive sampling (Klassen et al., 2012) yang terdiri dari mahasiswa Program Studi Pendidikan Biologi, Pendidikan Fisika, dan Pendidikan Kimia yang telah mengambil mata kuliah IPA Terpadu TA 2019/2020 yang berjumlah 164 orang. Instrumen penelitian yang digunakan adalah angket pengalaman belajar mahasiswa dan pedoman penilaian kualitas pertanyaan yang dibuat oleh peneliti. Data pengalaman belajar dan bentuk pertanyaan mahasiswa dikumpulkan melalui penyebaran angket secara daring (online). Pengalaman belajar mahasiswa yang diobservasi dalam penelitian ini meliputi apersepsi, pendahuluan, kegiatan inti, penutup dan penilaian. Masing-masing fase pembelajaran tersebut dipecah dalam bentuk indikator. Subjek penelitian diminta untuk memberikan respon "ya/tidak" pada setiap indikator yang ditanyakan. Tingkat signifikansi hubungan antara kualitas pertanyaan mahasiswa dan pengalaman belajar ditentukan dengan analisis regresi sederhana.

\section{HASIL DAN PEMBAHASAN}

\section{Hasil}

Gambaran kegiatan pada saat perkuliahan digali dengan menyebarkan angket kepada mahasiswa. Respon subjek penelitian dari masing-masing program studi di jurusan PMIPA terkait pengalaman belajar dapat dilihat pada Gambar 1 .

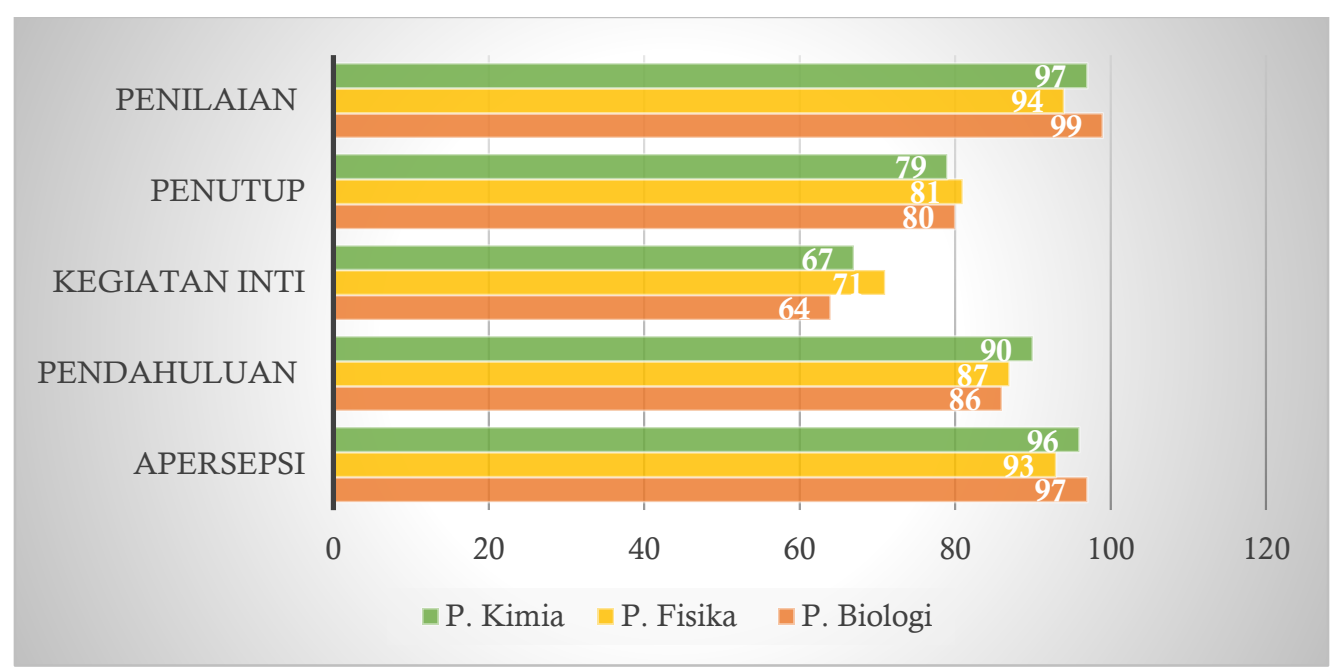

Gambar 1. Profil pengalaman belajar mahasiswa PMIPA Universitas Lampung 
Sementara itu, rerata respon pada masing-masing program studi di JPMIPA ditunjukkan pada Tabel 1.

Tabel 1. Rerata skor respon mahasiswa JPMIPA terhadap fase pembelajaran

\begin{tabular}{lcccccc}
\hline \multicolumn{1}{c}{ Subyek } & Apersepsi & Pendahuluan & Inti & Penutup & Penilaian & Rerata \\
\hline P. Biologi & 97 & 86 & 64 & 80 & 99 & 85 \\
P. Fisika & 93 & 87 & 71 & 81 & 94 & 85 \\
P. Kimia & 96 & 90 & 67 & 79 & 97 & 86 \\
Rerata & $\mathbf{9 5 , 3 3}$ & $\mathbf{8 7 , 6 7}$ & $\mathbf{6 6 , 3 3}$ & $\mathbf{8 0}$ & $\mathbf{9 6 , 6 7}$ & \\
\hline
\end{tabular}

Berdasarkan pedoman penafsiran Arikunto (2010), maka rerata masing-masing fase pembelajaran pada setiap program studi ditafsirkan sebagaimana data pada Tabel 2.

Tabel 2. Tafsiran data rerata fase pembelajaran pada setiap program studi

\begin{tabular}{lcc}
\hline \multicolumn{1}{c}{ Fase pembelajaran } & Rerata & Makna \\
\hline Apersepsi & 95,33 & Baik sekali \\
Pendahuluan & 87,67 & Baik sekali \\
Inti & 66,33 & Cukup \\
Penutup & 80 & Baik sekali \\
Penilaian & 96,67 & Baik sekali \\
\hline
\end{tabular}

Berdasarkan data pada Tabel 1. dapat diketahui bahwa rerata skor terendah dari masingmasing Program Studi terletak pada fase Inti. Rerata skor tertinggi dapat dilihat pada fase Penilaian yang disusul secara berurutan oleh fase Apersepsi, Pendahuluan, dan Penutup. Berdasarkan masing-masing Program Studi dapat dilihat bahwa skor tertinggi diperlihatkan oleh Pendidikan Kimia yang disusul oleh Pendidikan Fisika dan Pendidikan Biologi.

Sementara itu, Tabel 2. di atas menunjukkan bahwa seluruh fase pembelajaran yang dilakukan oleh mahasiswa pada Program Studi Pendidikan Biologi, Pendidikan Fisika dan Pendidikan Kimia berada pada tingkatan Cukup dan Baik sekali. Artinya, mahasiswa di PMIPA memandang bahwa kegiatan perkuliahan yang selama ini diikuti khususnya pada Matakuliah Biologi Dasar sudah baik dalam menunjang pencapaian tujuan pembelajaran.

Pengujian data diawali dengan uji normalitas untuk memenuhi asumsi dalam melakukan uji pengaruh. Hasil uji normalitas pada masing-masing program studi ditunjukkan pada Tabel 3.

Tabel 3. Hasil uji normalitas data pada setiap program studi

\begin{tabular}{lccc}
\hline Program studi & Nilai & Signifikansi & Makna \\
\hline P. Biologi & 0.167 & 0,05 & Normal \\
P. Fisika & 0.667 & 0.05 & Normal \\
P. Kimia & 0.197 & 0.05 & Normal \\
\hline
\end{tabular}


Hasil uji pengaruh antara kualitas pertanyaan dengan pengalaman belajar mahasiswa calon guru IPA ditunjukkan pada Tabel 4.

Tabel 4. Hasil uji pengaruh antara kualitas pertanyaan mahasiswa dengan pengalaman belajar

\begin{tabular}{lccccc}
\hline Program studi & Nilai & Signifikansi & t hitung & t tabel & Makna \\
\hline P. Biologi & 0.566 & 0,05 & 0,578 & 2,008 & Tidak signifikan \\
P. Fisika & 0.189 & 0.05 & 1,341 & 2,040 & Tidak signifikan \\
P. Kimia & 0.906 & 0.05 & 0,120 & 2,032 & Tidak signifikan \\
\hline
\end{tabular}

\section{Pembahasan}

\section{Profil Pengalaman Belajar Mahasiswa}

Sebagaimana hasil analisis yang telah ditunjukkan di atas, diketahui bahwa rerata skor tertinggi dari respon mahasiswa Pendidikan Biologi, Pendidikan Fisika dan Pendidikan Kimia ditunjukkan pada fase penilaian. Pandangan mahasiswa PMIPA terkait fase penilaian dalam perkuliahan adalah: (1) penilaian yang diberikan dosen dapat memicu semangat mahasiswa untuk meningkatkan hasil belajar; (2) penilaian sesuai dengan tujuan perkuliahan; (3) memberi penilaian terhadap sikap mahasiswa; (4) memberi penilaian terhadap keterampilan mahasiswa; (5) memberi penilaian terhadap aktivitas belajar mahasiswa; (6) menginformasikan jadwal sebelum dilakukan ujian; dan (7) mengalokasikan waktu ujian sesuai dengan jumlah dan tingkat kesukaran soal.

Berdasarkan pandangan tersebut, maka penilaian yang dilakukan dosen sudah mencakup tiga ranah hasil belajar yaitu sikap, keterampilan dan pengetahuan. Ketiga ranah tersebut merupakan hasil belajar yang tidak bisa dipisah-pisahkan dalam proses penilaian. Hasil belajar dapat menggambarkan tingkat kemajuan mahasiswa secara utuh apabila ketiga ranah hasil belajar tersebut diukur secara komprehensif (Supratiknya, A. 2012; Wulan, 2018). Secara psikologis, dampak penilaian yang dirasakan oleh mahasiswa adalah dapat meningkatkan semangat dalam prestasi belajar. Hal tersebut didukung oleh pernyataan Wulan (2018) yang menyimpulkan bahwa diantara fungsi penilaian adalah untuk/sebagai pembelajaran (for/as learning) (Wiono, 2020). Secara logis dapat dijelaskan bahwa mahasiswa dapat menemukan titik kesalahan/kekurangan pada kompetensi tertentu setelah dilakukan penilaian. Kemampuan mahasiswa dalam mengenali kesalahan/kekurangan sendiri selanjutnya oleh (Anderson \& Krathwohl, 2001) dimasukkan dalam Pengetahuan Metakognisi.

Selanjutnya, hasil analisis angket juga menginformasikan bahwa instrumen penilaian yang disusun oleh dosen menurut persepsi mahasiswa sudah mempertimbangkan aspek kesukaran dan alokasi waktu penyelesaian. Tingkat kesukaran oleh Arikunto et al., (2010) didefinisikan sebagai bilangan yang menunjukkan sukar atau mudahnya suatu soal diselesaikan. Terdapat metode statistik sendiri untuk menentukan tingkat kesukaran secara empiris. Butuh 
penelusuran lebih lanjut dengan mengonfirmasi kepada dosen yang bersangkutan untuk memastikan kebenaran bahwa analisis tingkat kesukaran sudah dilakukan terhadap instrumen soal.

Gambar 1 dan Tabel 1 di atas menginformasikan bahwa rerata skor terendah responden diberikan pada fase kegiatan inti perkuliahan. Rendahnya rerata skor pada fase kegiatan inti, menandakan bahwa terdapat indikator yang tidak muncul dalam proses tersebut. Indikator pada fase kegiatan inti terdapat dua puluh tujuh butir yang berbentuk pertanyaan investigatif. Indikator-indikator tersebut dikembangkan berdasarkan deskripsi. Terdapat delapan deskripsi yang digunakan dalam penelitian ini untuk mengungkap kondisi sebenarnya dari kegiatan inti perkuliahan. Deskripsi tersebut adalah: (1) kegiatan belajar menggunakan metode diskusi presentasi; (2) kegiatan belajar menggunakan metode ceramah; (3) dosen memberikan kesempatan bertanya; (4) dosen memberikan jawaban atas pertanyaan mahasiswa; (5) dosen menggunakan berbagai sumber belajar; (6) dosen menggunakan media pembelajaran yang menarik dan bervariasi; (7) dosen memanfaatkan hasil-hasil penelitian dan pengabdian kepada masyarakat untuk mendukung kegiatan perkuliahan; dan (8) dosen mendorong mahasiswa untuk menggunakan teknologi informasi dan komunikasi dalam kegiatan pembelajaran.

Secara rinci, indikator dari pertanyaan investigatif yang dikembangkan oleh tim peneliti disajikan pada Tabel 5. Kemudian, sebaran respon pada fase kegiatan inti dari mahasiswa JPMIPA dapat dilihat pada Gambar 2.

Tabel 5. Deskripsi dan indikator pertanyaan pada fase inti perkuliahan

\begin{tabular}{lll}
\hline No & Deskripsi & Indikator pertanyaan \\
\hline 1. & Kegiatan belajar & Diskusi dengan sesama mahasiswa \\
& menggunakan metode & Intensitas kegiatan presentasi berlangsung $(1-3,4-5,6-8,>8)$ \\
& diskusi presentasi. & Aktivitas diskusi difasilitasi dengan LKP \\
& & Diskusi dibantu mind map menggunakan dua tinggal dua bertamu \\
& & ke kelompok lain \\
& Menyatakan pendapat ketika diskusi \\
\hline 2. & Kegiatan belajar & Intensitas kegiatan ceramah berlangsung $(1-3,4-5,6-8,>8)$ \\
& menggunakan metode & Membuat laporan perkuliahan terkait materi yang disampaikan \\
& ceramah. & \\
\hline 3. & Dosen memberikan & Berani bertanya kepada dosen \\
& kesempatan bertanya. & Pelajaran yang sulit membuat bertanya \\
& & Bertanya membuat lebih paham \\
& & Tidak suka berdiam diri jika ada yang kurang dipahami, saya akan \\
& & bertanya kepada dosen \\
& & Bertanya hingga paham \\
\hline 4. & Dosen memberikan jawaban & Jawaban jelas dan to the poin \\
& atas pertanyaan mahasiswa. & \\
\hline 5. & Dosen menggunakan & Menggunakan hand out \\
berbagai sumber belajar. & Menggunakan buku dari penerbit \\
& & Menggunakan bahan ajar yang dibuat sendiri \\
\hline & &
\end{tabular}




\begin{tabular}{|c|c|c|}
\hline No & Deskripsi & Indikator pertanyaan \\
\hline & & Menggunakan laboratorium \\
\hline 6. & $\begin{array}{l}\text { Dosen menggunakan media } \\
\text { pembelajaran yang menarik } \\
\text { dan bervariasi. }\end{array}$ & $\begin{array}{l}\text { Menggunakan video pembelajaran } \\
\text { Menggunakan video pembelajaran interaktif }\end{array}$ \\
\hline 7. & $\begin{array}{l}\text { Dosen memanfaatkan hasil- } \\
\text { hasil penelitian dan } \\
\text { pengabdian kepada } \\
\text { masyarakat untuk } \\
\text { mendukung kegiatan } \\
\text { perkuliahan. }\end{array}$ & $\begin{array}{l}\text { Memberikan bahan belajar yang memuat hasil penelitian para } \\
\text { ilmuan } \\
\text { Menggunakan artikel dari jurnal bereputasi nasional } \\
\text { Menggunakan artikel dari jurnal bereputasi internasional }\end{array}$ \\
\hline 8. & $\begin{array}{l}\text { Dosen mendorong } \\
\text { mahasiswa untuk } \\
\text { menggunakan teknologi } \\
\text { informasi dan komunikasi } \\
\text { dalam kegiatan } \\
\text { pembelajaran. }\end{array}$ & $\begin{array}{l}\text { Mencari literatur dari internet } \\
\text { Menggunakan google classroom } \\
\text { Menggunakan virtual class } \\
\text { Menggunakan eduspot } \\
\text { Menggunakan siakadu }\end{array}$ \\
\hline
\end{tabular}

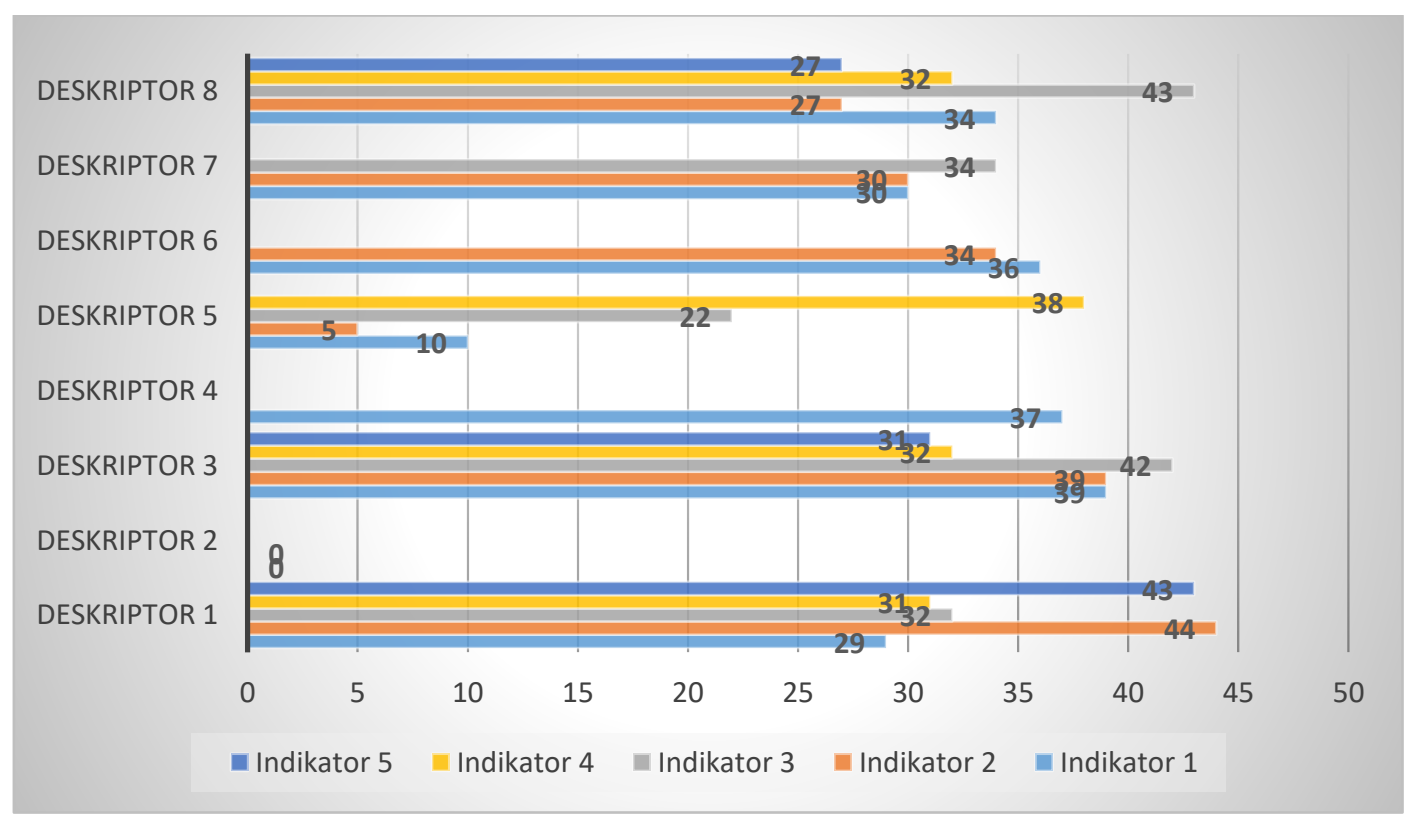

Gambar 2. Sebaran respon mahasiswa terhadap fase kegiatan inti perkuliahan

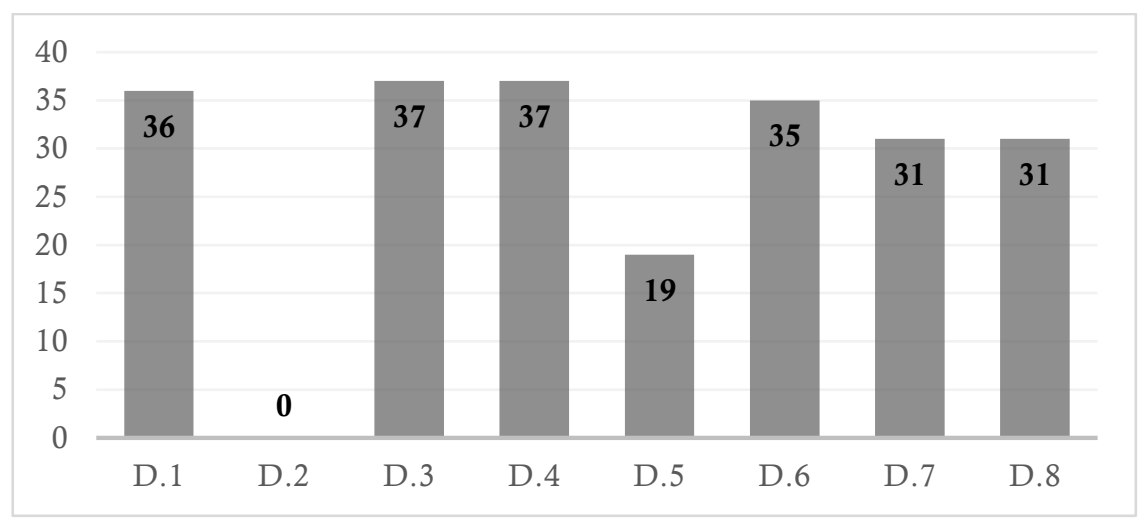


Gambar 3. Tingkat rerata dalam persen dari deskripsi fase kegiatan inti

Berdasarkan hasil analisis pada Gambar 2. dapat diketahui bahwa rerata respon terendah diperlihatkan pada deskripsi 2. Hal ini bermakna bahwa kegiatan pada fase inti perkuliahan yang diselenggarakan oleh dosen tidak menggunakan metode ceramah dan mahasiswa juga tidak diminta untuk membuat laporan perkuliahan melainkan dengan membuat jurnal mingguan yang berisi pertanyaan mahasiswa terhadap materi pembelajaran. Metode ceramah banyak mendapatkan kritik dari para Pakar Pendidikan IPA karena beberapa kelemahan yang dimilikinya yaitu berpusat pada guru dan membentuk pribadi pasif pada peserta didik (Devi, 2010; Marpaung, 2016). Membuat laporan perkuliahan bisa dalam bentuk catatan jurnal pembelajaran. Jurnal pembelajaran yang terintegrasi dengan strategi, model pembelajaran diketahui berkontribusi positif terhadap proses pembelajaran (Andriyani 2017), antara lain secara efektif meningkatkan keterampilan berpikir kritis siswa (Munawaroh et al., 2016); meningkatkan keterampilan metakognitif (Setiawan \& Susilo, 2015); meningkatkan kemampuan kerja ilmiah (Hidayati, 2017); serta meningkatkan motivasi belajar dan juga berpengaruh posistif terhadap penguasaan konsep siswa (Lianto et al., 2018).

Deskripsi 5 memiliki tingkat lebih tinggi dari Deskripsi 2 dengan rerata skor 18,75. Deskripsi 5 mengungkap apa saja sumber belajar yang digunakan oleh dosen ketika memfasilitasi perkuliahan. Indikator pertanyaan pada Deskripsi 5 yaitu: menggunakan sumber belajar hand out, buku ajar dosen yang bersangkutan, buku ajar bukan karya dosen yang bersangkutan, dan laboratorium. Office of the basic Education Commision (dalam Navy, 2013) menyatakan bahwa sumber belajar adalah komponen penting dalam mengelola pembelajaran karena dapat menumbuhkan minat siswa untuk belajar lebih dalam. Berdasarkan analisis data pada Gambar 3, berarti mahasiswa PMIPA memandang bahwa dosen pengajar sangat kurang dalam menggunakan sumber-sumber belajar ketika menyelenggarakan perkuliahan. Navy (2013) sudah menemukan dalam penelitiannya bahwa berkembangnya sumber-sumber belajar saat ini tidak sebanding dengan penggunaannya dalam proses perkuliahan. Terbukti di Jurusan PMIPA, bahwa sumber belajar yang digunakan dalam perkuliahan berada pada tingkat rendah. Sumber belajar yang digunakan dosen dalam perkuliahan secara berurutan adalah laboratorium, buku ajar dosen yang bersangkutan, hand out, dan buku ajar bukan karya dosen bersangkutan. Rendahnya penggunaan sumber belajar oleh Kanjanarakpong, S (dalam Navy, 2013) diprediksi akan mengganggu proses membangun pengetahuan pada siswa. Sedangkan dalam pandangan ahli pembelajaran konstruktivis, proses membangun (to construct) adalah inti dari proses pembelajaran sains (Glasersfeldh, V. dalam Waseso, 2018).

Deskripsi 7 dan 8 menempati peringkat lebih atas dari Deskripsi 5. Deskripsi 7 terkait dengan penggunaan hasil penelitian dan pengabdian dosen dalam kajian perkuliahan. Terdapat 
tiga indikator dalam Deskripsi 7, yaitu penggunaan hasil penelitian/pengabdian dosen, artikel dari jurnal nasional bereputasi dan artikel dari jurnal internasional. Data ini menggambarkan bahwa hasil-hasil penelitian kurang dimanfaatkan dalam perkuliahan.

Selanjutnya, Deskripsi 8 terkait dengan penggunaan teknologi informasi dan komunikasi dalam perkuliahan. Indikator pada Deskripsi 8 mencakup penggunaan internet dalam menemukan referensi perkuliahan dan pemanfaatan Learning Management System (LMS) dalam mengelola perkuliahan. Pihak Universitas Lampung telah memiliki LMS yang dinamakan $v$-class dan SIAKADU. Sedangkan Fakultas KIP sendiri juga sudah memiliki aplikasi yang dinamakan edusmart untuk mendukung pembelajaran dalam jaringan. Rupanya hal ini kurang dimanfaatkan oleh tim pengajar dalam memfasilitasi perkuliahan.

Peringkat selanjutnya berdasarkan analisis data pada Gambar 2 adalah Deskripsi 6 yang memuat penggunaan media pembelajaran yang digunakan dosen dalam perkuliahan. Berdasarkan data pada Gambar 2 terlihat bahwa dosen sangat jarang menggunakan media yang interaktif dan variatif ketika mengelola perkuliahan. Sementara itu, berdasarkan hasil-hasil penelitian terbukti bahwa penggunaan media dalam pembelajaran dapat meningkatkan prestasi dan motivasi belajar (Ekayani, 2017; Rafiuddin et al., 2017). Selain itu, penggunaan media pembelajaran yang tepat juga akan melatih dan menguatkan kemampuan spesifik pada siswa (Nataliya, 2015).

Deskripsi 1, 3 dan 4 secara berurutan menguak tentang penggunaan metode diskusi, presentasi dan tanya-jawab dalam perkuliahan. Berdasarkan hasil analisis data pada Gambar 2 dan Gambar 3 dapat diketahui bahwa aktivitas diskusi, presentasi dan tanya jawab masih jarang dilakukan. Metode diskusi yang divariasi diketahui dapat meningkatkan keterampilan mengajar mahasiswa (Nofiana, 2016), membentuk kemandirian belajar pada siswa (Kusumawati, 2016), dan juga mampu meningkatkan motivasi dan prestasi belajar siswa (Aswad, 2019). Selanjutnya, aktivitas tanya-jawab juga kurang terfasilitasi selama proses perkuliahan. Berdasarkan hasil penelitian, metode tanya-jawab terbukti efektif dalam meningkatkan pemahaman baru pada siswa (Setyowati, 2019).

\section{Pengaruh Pengalaman Belajar terhadap Kualitas Pertanyaan}

Berdasarkan hasil analisis yang ditunjukkan pada Tabel 4, dapat diketahui bahwa Pengalaman Belajar Mahasiswa di dalam perkuliahan tidak berpengaruh secara signifikan terhadap Kualitas Pertanyaan Mahasiswa. Data pada Tabel 4.1 menunjukkan bahwa fase kegiatan inti pada proses perkuliahan memiliki skor terendah diantara fase perkuliahan lainnya. Angka tersebut jika ditafsirkan dengan merujuk pada Arikunto et al., (2010) bermakna cukup. Makna tersebut dapat dijelaskan bahwa kebanyakan indikator yang seharusnya dihadirkan dalam kegiatan inti perkuliahan ternyata tidak muncul. 
Hasil analisis data pada Tabel 2 diketahui bahwa respon terendah mahasiswa JPMIPA pada pengalaman belajar terdapat pada fase kegiatan inti. Hal ini bermakna bahwa pada fase kegiatan inti perkuliahan terdapat banyak indikator yang tidak muncul. Kondisi ini terlihat tidak jauh berbeda pada masing-masing program studi, yaitu 64 (Pendidikan biologi), 71 (Pendidikan fisika), 67 (Pendidikan kimia), yaitu pada posisi terendah. Padahal, segala aktivitas penting dalam rangka meningkatkan pengetahuan dan keterampilan berada di fase kegiatan inti perkuliahan. Termasuk potensi dalam melatih kualitas pertanyaan mahasiswa.

Hasil analisis data pada Gambar 2 menunjukkan bahwa kegiatan inti perkuliahan tidak menggunakan metode ceramah. Perkuliahan berlangsung dengan diskusi kelompok, dimana masing-masing kelompok telah mendapatkan bagian topik tersendiri untuk dipresentasikan. Pertanyaan yang muncul pada saat proses diskusi kelas biasanya berada pada tingkatan berpikir rendah. Berikut adalah Tabel 6 yang memuat beberapa contoh bentuk pertanyaan dari responden.

Tabel 6. Bentuk-bentuk pertanyaan mahasiswa

\begin{tabular}{llll}
\hline Responden & Bentuk pertanyaan & Level & Keterangan \\
\hline $\begin{array}{l}\text { 1 (Mahasiswa Pendidikan } \\
\text { Biologi) }\end{array}$ & Apa yang dimaksud dengan fotosintesis? & $\mathrm{C} 1$ & recall \\
& Apa komponen utama dalam evolusi? & $\mathrm{C} 1$ & menyebutkan \\
$\begin{array}{l}\text { 2 (Mahasiswa Pendidikan } \\
\text { Fisika) }\end{array}$ & Apa yang disebut dengan ovulasi? & $\mathrm{C} 1$ & recall \\
& Apa saja tahapan dalam siklus sel? & $\mathrm{C} 2$ & menjelaskan \\
$\begin{array}{l}3 \text { (Mahasiswa Pendidikan } \\
\text { Kimia) }\end{array}$ & Apa sebab utama variasi genetik? & $\mathrm{C} 1$ & recall \\
& Apa perbedaan proses mitosis dan meiosis? & $\mathrm{C} 2$ & menjelaskan \\
\hline
\end{tabular}

Gambar 2 juga menunjukkan bahwa fase kegiatan inti perkuliahan tidak banyak menggunakan sumber belajar. Intensitas penggunaan sumber belajar sangat kecil pada hand out, buku ajar dan laboratorium. Kurangnya pendayagunaan berbagai sumber belajar diduga menjadi penyebab kecilnya rasa penasaran (curiousity) mahasiswa terhadap topik perkuliahan. Munculnya rasa penasaran pada seseorang merupakan indikator awal terbentuknya sebuah pertanyaan (Hopkins, 2008). Bagaimana bisa jika kemunculan indikator awal tidak distimulasi dengan optimal akan menghasilkan pertanyaan yang berkualitas.

Selain itu, ketiadaan hubungan antara pengalaman belajar dengan kualitas pertanyaan mahasiswa juga dapat disebabkan kurang terfasilitasinya aktivitas diskusi dan tanya jawab. Kedua aktivitas tersebut diduga kuat memiliki potensi besar dalam mengasah keterampilan membuat pertanyaan yang berkualitas. Disamping itu, kurangnya penggunaan media pembelajaran yang bervariasi; pemanfaatan hasil-hasil penelitian; dan penggunaan teknologi 
informasi dan komunikasi juga diindikasi memiliki peran pada hubungan pengalaman belajar dan kualitas pertanyaan mahasiswa.

\section{SIMPULAN}

Hasil penelitian ini menggambarkan bahwa ketiadaan hubungan antara kualitas pertanyaan mahasiswa dengan pengalaman belajar dikarenakan tidak terfasilitasinya latihan dalam menyusun pertanyaan yang berkualitas pada saat proses perkuliahan. Untuk memunculkan kemampuan menanya yang berkualitas pada mahasiswa diperlukan perlakuan yang terstruktur seperti membuat jurnal mingguan yang disertai dengan ulasan oleh dosen. Penggunaan strategi pembelajaran tertentu dapat diterapkan sebagai rencana penelitian selanjutnya.

\section{UCAPAN TERIMA KASIH}

Ucapan terima kasih kami sampaikan kepada pihak pimpinan Universitas Lampung yang telah menggulirkan program kompetisi hibah penelitian sehingga aktivitas tri darma dosen dapat berjalan lancar. Seluruh mahasiswa Jurusan Pendidikan Matematika dan Ilmu Pengetahuan Alam yang telah menjadi responden penelitian.

\section{REFERENSI}

Supratiknya, A. (2012). Penilaian Hasil Belajar dengan Teknik Nontes. Yogyakarta: Universitas Sanata Dharma.

Anderson, L. W., \& Krathwohl, D. R. (2001). A taxonomy for learning, teaching, and assessing: A revision of Bloom's taxonomy of educational objectives. Longman,.

Andriyani, F. D. (2017). Kontribusi Penggunaan Jurnal Belajar Pada Pembelajaran Matakuliah Permainan Bolabasket. Jurnal Cakrawala Pendidikan, 36(1), 140-147. https://doi.org/10.21831/cp.v36i1.11976

Arikunto, S., Suhardjono, \& Supardi. (2010). Penelitian Tindakan Kelas. Jakarta: Bumi Aksara.

Aswad, H. (2019). Efektivitas Pelaksanaan Metode Diskusi Kelompok Terpusat (Focus Group Discussion) Terhadap Motivasi Belajar IPS Murid Kelas V SD Negeri II Bone-Bone Kota Baubau. PERNIK: Jurnal Pendidikan Anak Usia Dini, 2(2), 135-160. https://doi.org/10.31851/ pernik.v2i01.3112

Devi, P. K. (2010). Metode-metode dalam pembelajaran IPA. Bandung: Pusat Pengembangan dan Pemberdayaan Pendidik dan Tenaga Kependidikan IPA.

Ekayani, P. (2017). Pentingnya penggunaan media pembelajaran untuk meningkatkan prestasi belajar siswa. Jurnal Fakultas Ilmu Pendidikan Universitas Pendidikan Ganesha Singaraja, 2(1), $1-11$. 
Hasnunidah, N. (2016). Pengaruh Argument-Driven Inquiry dengan Scaffolding dan Kemampuan Akademik terhadap Keterampilan Argumentasi, Keterampilan Berpikir Kritis, dan Pemahaman Konsep Biologi Dasar Mahasiswa Jurusan PMIPA Universitas Lampung. (Master's thesis) Universitas Negeri Malang.

Hidayati, N. (2017). Pembelajaran Discovery Disertai Penulisan Jurnal Belajar Untuk Meningkatkan Kemampuan Kerja Ilmiah Siswa Kelas VIII.1 SMP Negeri 1 Probolinggo. Jurnal Penelitian Pendidikan IPA, 1(2), 52-61. https://doi.org/10.26740/jppipa.v1n2.p52-61

Hopkins, D. (2008). A Teacher's Guide to Classroom Research. In Mc Graw Hill Open University Press (4th ed., Vol. 29, Issue 3). Mc Graw Hill Open University Press. https://doi.org/10.1080/13674580300200452

Klassen, A. C., Creswell, J., Plano Clark, V. L., Smith, K. C., \& Meissner, H. I. (2012). Best Practices in Mixed Methods for Quality of Life Research. Quality of Life Research, 21(3), 377-380. https://doi.org/10.1007/s11136-012-0122-x

Kusumawati, A. I. (2016). Efektivitas Metode Diskusi dan Metode Talking Stick terhadap Prestasi Belajar serta Pengaruhnya Terhadap Kemandirian Belajar Siswa. Jurnal Riset Pendidikan Ekonomi, 1(1), 1-5.

Lianto, Jufri, A. W., \& Merta, I. W. (2018). Pemanfaatan Model Jurnal Belajar Kotak Berhias untuk Meningkatkan Motivasi dan Hasil Belajar. Prosiding Seminar Nasional Pendidikan Biologi, 1(1), 500-504.

Marpaung, J. (2016). Pengaruh Penerapan Metode Ceramah Plus dengan Metode Resitasi Terhadap Motivasi Belajar Mahasiswa Bimbingan Konseling Universitas Riau Kepulauan Batam. KOPASTA: Journal of the Counseling Guidance Study Program, 3(2), 56-68.

Munawaroh, L., Pantiwati, Y., \& Rofieq, A. (2016). Penggunaan Jurnal Belajar Dalam Pembelajaran Class Wide Peer Tutoring Terhadap Kemampuan Berpikir Kritis Siswa. Jurnal Pendidikan Biologi Indonesia, 1(3), 263-273. https://doi.org/10.22219/jpbi.v1i3.2659

Nasution, M. I. P. (2016). Strategi pembelajaran efektif berbasis mobile learning pada sekolah dasar. IQRA': Jurnal Perpustakaan dan Informasi, 10(1)., 1-14.

Nataliya, P. (2015). Efektivitas Penggunaan Media Pembelajaran Permainan Tradisional Congklak Untuk Meningkatkan Kemampuan Berhitung Pada Siswa Sekolah Dasar. Jurnal Ilmiah Psikologi Terapan (JIPT), 03(02), 343-358. https://doi.org/10.22219/jipt.v3i2.3536

Navy, A. (2014). Manajemen Sumber Belajar dalam Meningkatkan Mutu Pembelajaran Sains (Studi kasus di Pratomseksa (SD) Sassanasuksa Thailand). Jurnal Pendidikan Humaniora, 1(4), 388-395.

Nofiana, M. (2016). Efektivitas Penerapan Metode Diskusi-Simulasi terhadap Keterampilan Mengajar Mahasiswa Calon Guru Biologi. JEMS (Jurnal Edukasi Matematika dan Sains), $4(2), 85-95$. 
Oktaviana, K., Hidayati, S., \& Wibowo, Y. (2016). Ragam Pertanyaan Guru dan Siswa dalam Pembelajaran Biologi di MAN Kotamadya Yogyakarta. Jurnal Pendidikan Biologi, 5(7), 8 18.

Rafiuddin, Basri, M., \& Azis, M. (2017). Urgensi Penggunaan Media dalam Proses Pembelajaran Bagi Guru Sekolah Dasar Wilayah II Kecamatan Sanrobone Kabupaten Takalar Provinsi Sulawesi Selatan. Prosiding Teknologi Pembelajaran dan Pendidikan Dasar 2017, 2(3), 147-157.

Setiawan, D., \& Susilo, H. (2015). Peningkatan Keterampilan Metakognitif Mahasiswa Program Studi Biologi Melalui Penerapan Jurnal Belajar Dengan Strategi Jigsaw Dipadu PBL Berbasis Lesson Study Pada Matakuliah Biologi Umum. Prosiding Seminar Nasional Pendidikan Biologi (Vol. 2009, pp. 359-369).

Setyowati, W. (2019). Keefektivitasan Pembelajaran Bahasa Mandarin Menggunakan Metode Tanya Jawab dengan Media Presentasi Prezi pada Siswa Kelas 3 SD Mandala II Surabaya. Prosiding Seminar Nasional Ilmu Terapan (SNITER), 1(1), B21-B21.

Walsh, J. A., \& Sattes, B. D. (2016). Quality Questioning: Research-based practice to engage every learner (pp. 1-129). Corwin a Sage Company - Mc-Rel International.

Waseso, H. P. (2018). Kurikulum 2013 dalam prespektif teori pembelajaran konstruktivis. TA'LIM: Jurnal Studi Pendidikan Islam, 1(1), 59-72.

Widyatama, A., Kartini, H., \& Hanifah, N. (2016). Penerapan model two stay two stray untuk meningkatkan kemampuan bertanya dan menjawab pada siswa kelas V SDN 2 Curahsuri Kabupaten Situbondo oleh Agung Widyatama. (Thesis). Universitas Negeri Malang.

Wiono, W. J. (2020). The Contribution of Learning Journal in Botany Phanerogamae Course. Proceedings of the International Conference on Progressive Education (ICOPE 2019). 44-47. https://doi.org/10.2991/assehr.k.200323.087

Wulan, A. R. (2018). Menggunakan Asesmen Kinerja untuk Pembelajaran Sains dan Penelitian (pp. 50-51). UPI Press. 